\title{
UJI PH DAN KARAKTER FISIK KUALITAS AIR DI PEMUKIMAN PABRIK KELAPA SAWIT (PKS) NAGA SAKTI TAPUNG HILIR
}

\author{
Endang Susi Lestari, Shabri Putra Wirman, Noni Febriani, Aji Suroso \\ Prodi Studi Fisika, Fakultas MIPA dan Kesehatan \\ Universitas Muhammadiyah Riau
}

\begin{abstract}
Water is the source of life for all living beings on this earth. Some sources of water for daily needs comes from shallow wells, artesian wells, springs, surface water and rain water collection. The Naga Sakti cottage settlements is one of the settlements adjacent to the Palm Oil Mill (POM) in the district of Lower Tapung Riau Kampar district, and the location of settlements in the area of oil palm plantations. Water produced from wells on the settlement sometimes colored and taste. therefore necessary to test the water $\mathrm{pH}$ and physical to determine whether the water in the wells meet the Ministry of Health of the Republic of Indonesia Number: 416/MENKES/PER/IX/1990 about water quality requirements with a $p H$ test and physical parameters that include viscosity, Total Dissolved solids (TDS), Density, conductivity, Oxidation Reduction Potential (ORP), resistivity, salinity, and taste test. Water quality testing was conducted at a radius of $4 \mathrm{~km}$ to $8 \mathrm{~km}$ from the MCC. From the results of the $\mathrm{pH}$ test has been done, there are three that are close to the standard radius PERMENKES ie a radius of 4, 5 and 6 miles. As for the $8 \mathrm{~km}$ radius $\mathrm{pH}$ values far below the standard Permenkes at pH test. Then to test all the physical radius PERMENKES already meet the standards, in the form of test viscosity, density, ORP, TDS, salinity, conductivity, resistivit , and flavor.
\end{abstract}

Keywords: Water, POM, pH, Physical, Viscosity, Dissolved solids, conductivity, Oxidation Reduction Potential, Resistivity, Salinity.

\section{PENDAHULUAN}

Air merupakan sumber kehidupan bagi seluruh makhluk hidup di muka bumi ini. Air dapat ditemukan hampir di seluruh penjuru dunia, dan itu semua karena air merupakan sumber daya alam yang tak terbatas. Beberapa sumber air untuk kebutuhan sehari-hari berasal dari sumur dangkal, sumur artesis, mata air, air permukaan dan penampung air hujan. Sumber air merupakan salah satu faktor yang menentukan kualitas air. Kualitas air pada sumber air dipengaruhi oleh faktor lingkungan sekitar serta keadaan tanah pada daerah sumber air berasal.

Air memiliki peranan yang sangat penting dalam kehidupan manusia, karena memiliki banyak manfaat yang dibutuhkan bagi manusia. Manfaat tersebut dapat dirasakan baik di dalam maupun luar tubuh manusia. Beberapa fungsi utama air bagi manusia diantaranya yaitu sebagai air minum dan untuk keperluan kebersihan seperti mandi, mencuci dan lain sebagainya.
Untuk kebutuhan itu semua diperlukan air yang layak, yaitu air bersih dan memenuhi standar. Air bersih yaitu air yang tidak tercemar oleh limbah maupun zat-zat kimia yang membahayakan dan memenuhi syarat kesehatan.

Semakin bertambahnya penduduk maka semakin bertambah juga jumlah air bersih yang dibutuhkan. Dengan bertambahnya penduduk tersebut, memungkinkan pencemaran lingkungan semakin meningkat, termasuk juga dengan pencemaran air. Hal tersebut menyebabkan air menjadi tidak layak pakai, yang dikarenakan tidak memenuhi syarat air bersih. Sedangkan untuk kebutuhan air bersih semakin sulit didapat, terutama pada daerah di sekitar wilayah kota-kota besar dan kawasan perindustrian.

Pemukiman Naga Sakti Pondok Satu adalah salah satu pemukiman yang berdekatan dengan Pabrik Kelapa Sawit (PKS) di Kecamatan Tapung Hilir kabupaten Kampar Riau, dan lokasi 
pemukiman tersebut di dalam area kebun kelapa sawit.

Sumber air pada pemukiman tersebut yaitu berupa sumur cincin. Letak dari sumur tersebut berada di luar rumah dan ada beberapa sumur yang terbuka tanpa

\section{METODOLOGI PENELITIAN}

\section{Alat}

Alat yang digunakan dalam penelitian ini antara lain Botol air mineral $600 \mathrm{ml}, 1$ set $\mathrm{pH}$ meter dengan Portable $\mathrm{pH} /$ Conductivity/ ORP/DO Meter, 1 set tabung viskometer ostwald, Gelas ukur, Neraca digital, stopwatch, dan pipet tetes.

\section{Bahan}

Bahan yang akan digunakan dalam penelitian ini adalah sampel air yang di ambil dari beberapa sumur pemukiman warga dengan radius yang berbeda dan tissue.

\section{Prosedur Kerja}

Metodologi pada penelitian ini yaitu dengan mengambil beberapa sampel air sumur dari pemukiman di dalam area PKS PT. Naga Sakti Tapung Hilir, dimana masing-masing perumahan tersebut berada pada jarak 4, 5, 6 dan $8 \mathrm{~km}$ dari PKS. Pada setiap lokasi pengambilan sampel air, akan diambil 4 sampel air pada sumur yang berbeda pada pemukiman tersebut sebanyak 2 liter air sampel. Selain sampel air yang akan diuji, digunakan juga air PAM (Perusahaan Air Minum) PT. Naga Sakti Tapung Hilir.

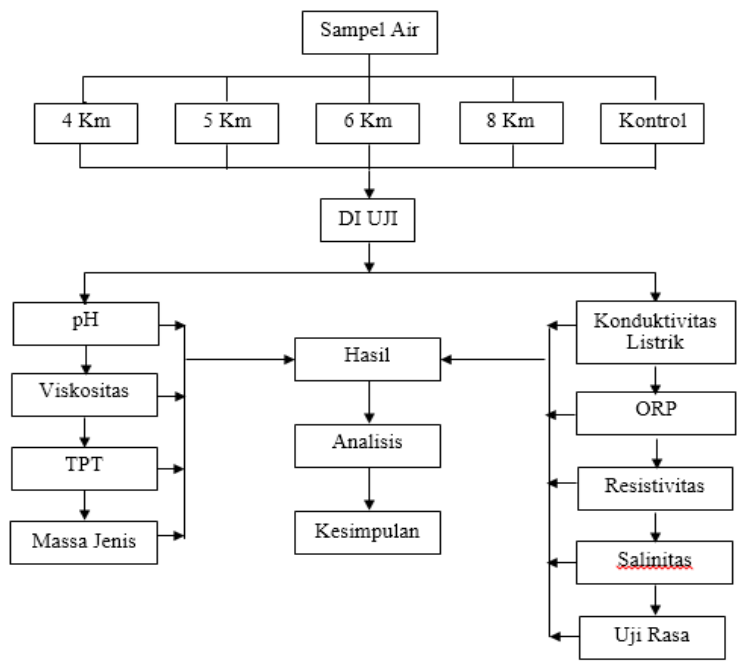

Gambar. 1. Diagram Alir Penelitian

\section{Uji pH}

Pada uji pH sampel air akan diukur dengan $\mathrm{pH}$ meter yang bekerja berdasarkan prinsip elektrolit/konduktivitas suatu larutan. Cara penggunaanya yaitu dengan memasukkan alat ini kedalam air yang ingin diketahui nilai pHnya. Ulangi pengukuran sebanyak 5 kali.

\section{Uji Viskositas}

Uji Viskositas dilakukan menggunakan viskometer Ostwald dengan cara memasukan air kedalam alat viskometer Ostwald. Cara menggunakan viscometer Ostwald (Gambar 137) yaitu, air dipakai sebagai pembanding, pertama air dimasukkan melalui tabung A kemudian dihisap agar masuk ketabung B tepat sampai batas a kemudian dilepaskan dan siapkan stopwatch sebagai pengukur waktu. Jika waktu yang diperlukan air untuk bergerak dari permukaan a sampai $b$ adalah $t 1$, maka percobaan diganti dengan zat cair lain dengan cara yang sama seperti Gambar 2 di bawah ini.

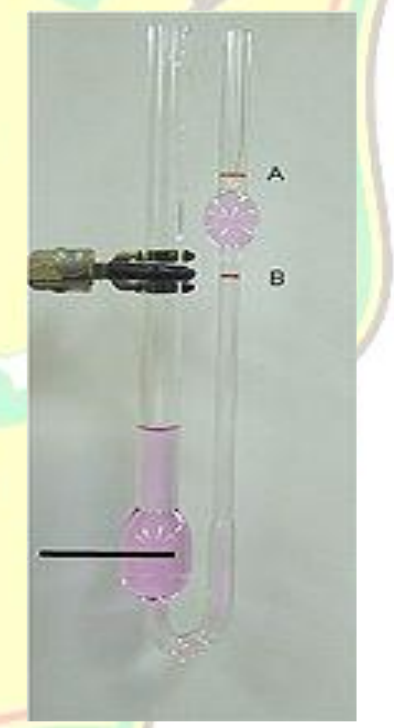

Gambar. 2. Viskometer Ostwald

Jika diperlukan $\mathrm{t} 2$ dengan menggunakan rumus Poiseville karena V, L dan R sama maka didapat persamaan:

$$
\frac{\eta_{1}}{\eta_{2}}=\frac{T_{1}}{T_{2}} \frac{\rho_{1}}{\rho_{2}}
$$

Dengan $\gamma_{1}$ adalah massa jenis air 1 dan $\gamma_{2}$ merupakan massa jenis zat cair yang dicari. Pada viscometer Ostwald yang diukur adalah waktu yang dibutuhkan oleh sejumlah air 
tertentu untuk mengalir melalui pipa kapiler yang disebabkan oleh berat air itu sendiri, jadi waktu yang dibutuhkan oleh air untuk melalui batas "a" dan "b" dapat diukur menggunakan stop watch [11].

\section{Uji Massa Jenis}

Seperti uji fisis sebelumnya pada uji massa jenis juga menggunakan air dari keempat sampel air yang telah diambil dengan metode pengujiannya yaitu :

1. Menimbang massa dari gelas ukur

2. Memasukkan air kedalam gelas ukur sebanyak $25 \mathrm{ml}$.

3. Menimbang gelas ukur yang berisi sampel air dengan neraca digital. Kemudian hasil dari massa tersebut dikurangi dengan massa gelas ukur untuk mendapatkan massa air.

4. Mengulangi percobaan sebanyak 5 kali.

5. Menghitung data rata-rata dari pengulangan dengan persamaan (2.2).

$\rho=\frac{m}{v}$

\section{Oxidation Reduction Potential (ORP)}

Uji Oxidation Reduction Potential (ORP) dilakukan dengan menggunakan alat dan cara yang sama seperti uji $\mathrm{pH}$ dan konduktivitas di atas. Uji ORP dilakukan untuk mengetahui tingkat kemampuan air dalam membunuh bakteri yang terkandung di dalamnya

\section{Uji Tottal Disolve Solid (TDS)/Total PadatanTerlarut (TPT)}

Uji TPT dilakukan dengan menggunakan alat yang sama dengan $\mathrm{pH}$ meter. Alat tersebut memiliki fungsi yang sama yaitu hanya dengan menekan tombol function pada layar (display) alat pengukuran. Cara pengujian dengan alat ini yaitu dengan memasukkan alat ini ke dalam air yang ingin diketahui nilai TPT tersebut. Dalam pengujian tersebut dilakukan pengulangan sebanyak 5 kali.

\section{Salinitas}

Uji salinitas dilakukan untuk mengetahui kadar garam yang terkandung didalamnya. Cara yang dilakukan untuk uji salinitas yaitu sama dengan TPT, konduktivitas dan resisitivitas di atas.

\section{Uji Konduktivitas}

Uji konduktivitas juga dilakukan dengan menggunakan alat yang sama dengan $\mathrm{pH}$ meter. Hanya saja probe (alat pendeteksi $\mathrm{pH}$ diganti dengan konduktivitas). Cara kerjanya sama, yaitu dengan menekan tombol function pada layar (display) alat pengukuran dan memasukkan alat ke dalam air. Pengujian juga dilakukan dengan mengulanginya sebanyak 5 kali.

\section{Uji Resistivitas}

Sama dengan uji yang lainnya, uji resistivitas dilakukan untuk mencari kemampuan suatu zat dalam menghambat aliran listrik. Cara yang dilakukan pada uji resistivitas sama dengan konduktivitas. Perbedaanya hanya menekan tombol function pada display alat ke dalam fungsi resistivitas.

\section{Uji Organoleptik}

Uji rasa dilakukan dengan cara memberikan sampel air kepada beberapa orang dewasa berjenis kelamin laki-laki dan perempuan untuk meminum atau cukup berkumur saja. Kemudian mengisi kuesioner yang berisi kualitas air dari segi rasa, dengan variasi rasa "berasa" dan "tidak berasa".

\section{HASIL DAN PEMBAHASAN pH}

Berdasarkan Gambar 3 nilai $\mathrm{pH}$ pada masingmasing radius berbeda-beda. Pada hari pertama menunjukkan jika nilai $\mathrm{pH}$ dari radius 4 hingga 8 semakin menurun. Dan pengukuran nilai $\mathrm{pH}$ dihari kedua juga menurun dan lebih kecil dibandingkan dengan hari pertama. Kemudian pada pengukuran nilai $\mathrm{pH}$ dihari ketiga untuk sampel air radius 4 hingga $6 \mathrm{~km}$ cenderung sama dengan hari kedua.

Nilai $\mathrm{pH}$ tersebut berbeda dengan sampel air pada radius $8 \mathrm{~km}$. Pada radius tersebut nilai $\mathrm{pH}$ semakin menurun dan memiliki nilai yang lebih kecil dibandingkan dengan hari sebelumnya. Tidak hanya pada sampel masing-masing radius, sampel air PAM yang digunakan sebagai 
pembanding juga menurun pada pengukuran dihari yang berbeda.

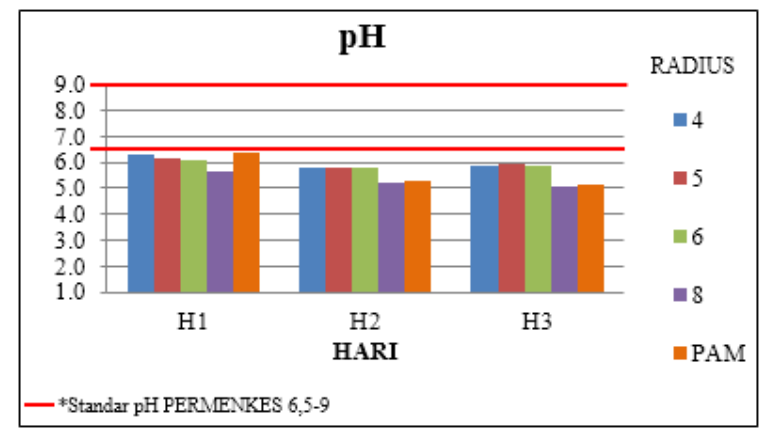

Gambar. 3. Hubungan nilai $\mathrm{pH}$ dengan hari dan radius yang berbeda

Perbedaan nilai $\mathrm{pH}$ tersebut dapat disebabkan karena adanya perbedaan suhu saat pengukuran nilai $\mathrm{pH}$ pada masing-masing hari tersebut. Dimana suhu pada hari pertama adalah $28^{\circ} \mathrm{C}$, hari kedua adalah $29^{\circ} \mathrm{C}$ dan di hari ketiga yaitu $30^{\circ} \mathrm{C}$. Semakin naik suhu pada saat pengambilan sampel dan pengukuran, maka nilai $\mathrm{pH}$ akan semakin turun.

Perbedaan tersebut juga dapat disebabkan karena pada karena air pada sumur tercampur dengan air hujan. Maka dari itu nilai $\mathrm{pH}$ pada radius tersebut masih memenuhi standar PERMENKES yaitu dengan nilai $\mathrm{pH}$ air hujan sebesar 5,5.

Faktor perbedaan nilai pada masing-masing radius yaitu faktor dari kondisi tanah dan lokasi sumur pada masing-masing radius tersebut. Air sumur yang terletak pada dataran rendah dapat dikatakan air sumur dengan kualitas yang rendah dibandingkan dengan air sumur pada datarn tinggi. Hal tersebut dikarenakan air yang mengalir dari dataran tinggi menuju ke dataran rendah membawa berbagai macam zat dalam alirannya tersebut. Dan lokasi sumur yang diambil yaitu semakin jauh dari PKS tanah semakin datar dan menurun. Sehingga pada radius $8 \mathrm{~km}$ terletak pada dataran yang lebih rendah dari raidus lainnya dan PKS [4].

Dari nilai $\mathrm{pH}$ yang diperoleh pada hari pertama dikatakan lebih baik dibandingkan dengan yang lain. Dimana nilai $\mathrm{pH}$ pada hari pertama mendekati dengan nilai $\mathrm{pH}$ yang sesuai dengan Peraturan Menteri Kesehatan Republik Indonesia Nomor : 416/MENKES/ PER/IX/1990 tentang syarat kualitas air bersih yaitu 6,5 - 9 .
Dan nilai pH pada hari pertama untuk semua radius 4 hingga $6 \mathrm{~km}$ berkisar antara $6,0-6,4$ dan nilai $\mathrm{pH}$ untuk air PAM yaitu 6,35. Sedangkan untuk radius $8 \mathrm{~km}$ dan pada hari lainnya nilai $\mathrm{pH}$ cukup berada di bawah PERMENKES yaitu 5,8 [6].

\section{Viskositas}

Nilai viskositas yang ditunjukkan pada Gambar 4 dari hari pertama dan kedua nilai viskositas pada semua radius tidak jauh berbeda. Sedangkan hari ketiga nilai viskositas menurun dari hari sebelumnya. Hari pertama dan kedua nilai viskositas juga cenderung sama untuk semua radius dan air PAM. Besar nilai viskositas dihari pertama dan kedua yaitu $1,2555-1,3500 \mathrm{Ns} / \mathrm{m}^{2}$. Sedangkan pada hari ketiga nilai viskositas untuk semua radius dan air PAM menurun hingga $1,1000 \mathrm{Ns} / \mathrm{m}^{2}$.

Perbedaan nilai viskositas tersebut juga dapat disebabkan adanya perbedaan suhu pada setiap pengambilan. Dimana suhu pada hari pertama adalah $28^{\circ} \mathrm{C}$, hari kedua adalah $29^{\circ} \mathrm{C}$ dan di hari ketiga yaitu $30^{\circ} \mathrm{C}$. Pada hari pertama dan kedua perbedaan suhu tidak terlalu jauh sehingga tidak memberikan pengaruh yang cukup besar pada nilai viskositas dihari kedua. Sedangkan dihari ketiga suhu pengambilan cukup tinggi, sehingga memberikan pengaruh yang cukup besar pada nilai viskositas.

Kekentalan suatu cairan dipengaruhi oleh suhu, jika suhu cairan meningkat maka kekentalan akan menurun dan sebaliknya jika suhu cairan turun maka kekentalan cairan meningkat [9]

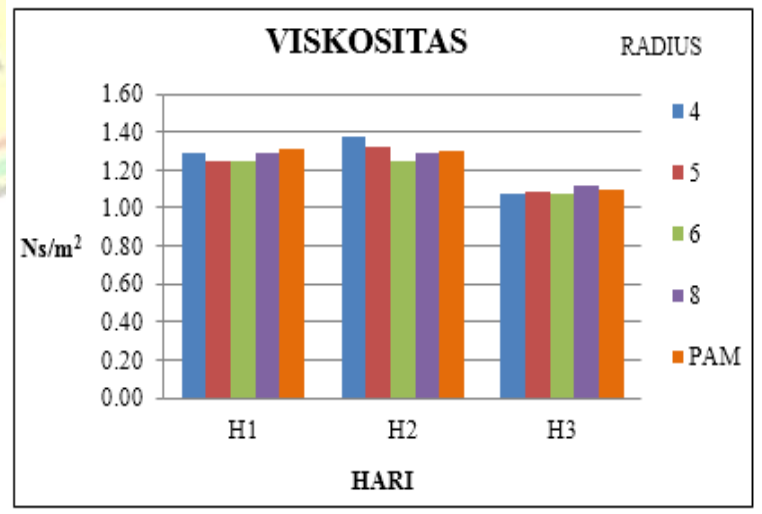

Gambar. 4. Hubungan nilai viskositas dengan radius yang berbeda 


\section{Massa Jenis}

Massa jenis merupakan perbandingan antara massa dan volume suatu cairan. Gambar 5 menunjukkan hasil nilai massa jenis air sumur dengan radius 4, 5, 6 dan $8 \mathrm{~km}$ dari PKS.

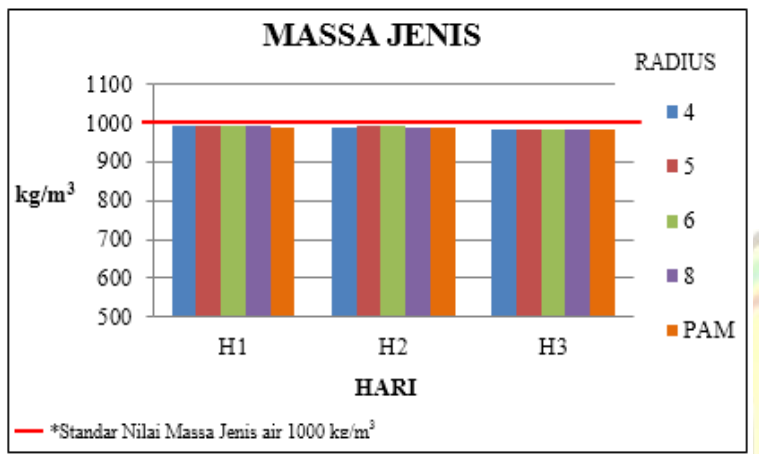

Gambar. 5. Hubungan nilai Massa Jenis dengan radius yang berbeda

Dari gambar tersebut dapat dilihat jika nilai massa jenis untuk semua radius mendekati nilai yang telah ditentukan oleh PERMENKES yaitu $1000 \mathrm{~kg} / \mathrm{m}^{3}$. Nilai massa jenis dari semua radius tersebut berkisar antara $980-992 \mathrm{~kg} / \mathrm{m}^{3}$. Dengan perbedaan nilai massa jenis yang tidak terlalu jauh tersebut maka air pada semua radius memenuhi syarat kualitas air yang baik dari PERMENKES [6].

\section{Oxidation Reduction Potential (ORP)}

Gambar 6 menunjukkan nilai ORP untuk masing-masing radius dengan pengambilan sampel 3 kali dalam waktu (hari) yang berbeda.

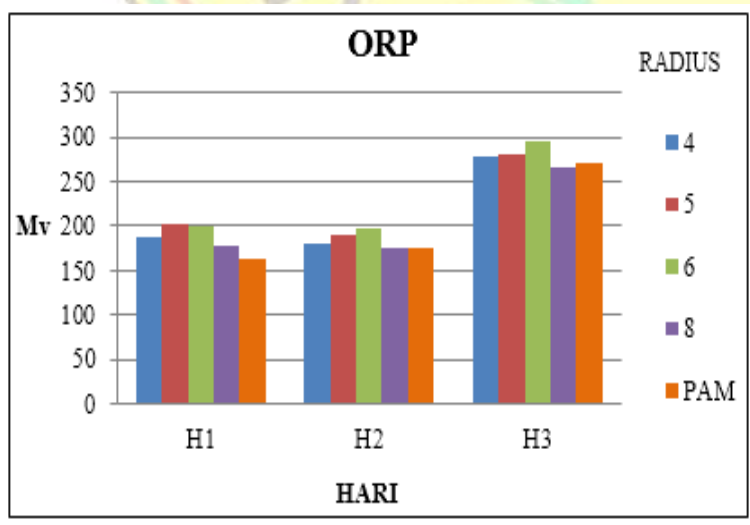

Gambar. 6. Hubungan Nilai ORP dengan radius yang berbeda

ORP menunjukkan tingkat kemampuan suatu cairan dalam membunuh bakteri dalam cairan tersebut. Semakin tinggi nilai ORP maka akan semakin cepat waktu yang dibutuhkan dalam membunuh bakteri tersebut. Pada gambar tersebut ditunjukkan jika nilai ORP untuk semua radius dan air PAM cendereng sama dihari kedua dan naik dihari ketiga. Kenaikan nilai ORP tersebut diiringi dengan kenaikan suhu pada setiap pengukuran nilai tersebut. Nilai ORP pada masing-masing radius berbeda, namun perbedaan itu tidak terlalu jauh. Nilai ORP yang dihasilkan pada hari ketiga cukup tinggi yaitu pada rentang 270-295 mV.

Dari nilai ORP tersebut maka pada hari ketiga kemampuan air dalam membunuh bakteri membutuhkan waktu yang lebih cepat dibandingkan dengan hari lainnya. Hal tersebut karena nilai ORP pada hari ketiga lebih tinggi dibandingkan dengan hari lainnya [12].

\section{Tottal Disolve Solid (TDS)/ Total Padatan Terlarut (TPT)}

Dari Gambar 7 nilai TDS pada masingmasing radius bebeda-beda. Pengukuran pada hari yang berbeda juga menyebabkan perbedaan nilai TDS pada masing-masing radius. Dihari pertama nilai TDS untuk radius 4 hingga $6 \mathrm{~km}$ dan untuk air PAM memiliki nilai yang cukup rendah dan naik dihari kedua. Kemudian dihari berikutnya nilai TDS pada radius tersebut menurun kembali. Pada hari kedua pengukuran nilai TDS tertinggi terdapat pada sumur dengan radius $4 \mathrm{~km}$. Dilingkungan sekitar sumur pada radius $4 \mathrm{~km}$ berdekatan dengan selokan sehingga air sumur dapat terkontaminasi dengan air yang terdapat di selokan tersebut pada saat turun hujan. Sehingga dapat menyebabkan air pada sumur radius $4 \mathrm{~km}$ memiliki nilai TDS yang berbeda dengan air pada radius lainnya.

Hasil yang berbeda ditunjukkan pada radius $8 \mathrm{~km}$ dengan nilai yang cukup rendah dibandingkan radius lainnya. Faktor perbedaan nilai TDS pada radius $8 \mathrm{~km}$ dapat disebabkan karena lokasi sumur yang berada pada dataran rendah.. Air yang mengalir dari dataran tinggi menuju ke dataran rendah membawa berbagai macam zat dalam alirannya tersebut. Sehingga menyebabkan nilai TDS menjadi besar pada radius $8 \mathrm{~km}$. Pada lingkungan sumur tersebut terdapat rumah warga yang berprofesi pembuat tahu. Dalam hari (waktu) tertentu pembuat tahu tersebut melakukan pembuangan limbah. 


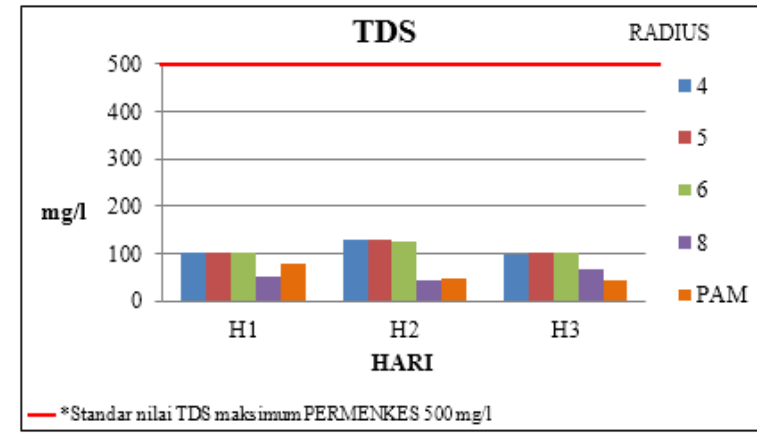

Gambar. 7. Hubungan nilai TDS dengan radius yang berbeda

\section{Salinitas}

Salinitas merupakan kadar garam suatu cairan atau banyak sedikitnya kandungan garam yang terkandung dalam suatu cairan tersebut. Gambar 8 menunjukkan hasil dari nilai salinitas pada air sumur dengan radius 4 hingga $8 \mathrm{~km}$ dari PKS

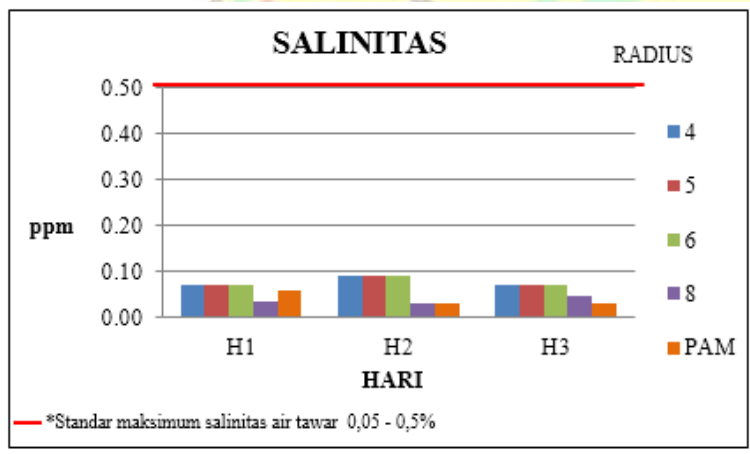

Gambar. 8. Hubungan nilai Salinitas dengan radius yang berbeda

Nilai yang ditunjukkan pada gambar tersebut hampir sama untuk radius 4-6 km. Pada hari kedua nilai salinitas cenderung naik untuk semua radius tersebut, dan nilai terbesar terdapat pada radius sumur pertama. Faktor perbedaan nilai salinitas pada radius $4 \mathrm{~km}$ adalah sama dengan faktor penyebab pada nilai TDS di atas, yaitu adanya selokan disekitar sumur tersebut. Kemudian pada pengambilan hari ketiga nilai salinitas menurun kembali untuk radius $4 \mathrm{~km}$.

Hasil yang berbeda ditunjukkan pada radius $8 \mathrm{~km}$ dengan nilai salinitas yang cukup rendah dibandingkan dengan raidus lainnya. Akan tetapi terdapat satu sumur pada radius tersebut yang memiliki nilai tinggi yaitu $8 \mathrm{~km}$, dimana nilai tersebut diambil pada hari ketiga. Nilai tinggi pada radius $8 \mathrm{~km}$ juga dapat dipengaruhi adanya pembuat tahu pada lingkungan sumur tersebut.
Untuk nilai salinitas pada radius 4-6 km berada di atas nilai salinitas air PAM yang digunakan sebagai pembanding. Sedangkan pada radius 8 $\mathrm{km}$ nilai berada di bawah air PAM untuk hari pertama dan kedua. Kemudian berada di atas air PAM pada hari ketiga.

Akan tetapi nilai salinitas pada semua radius masih diperbolehkan karena tidak melebihi batas nilai ketetapan pada air tawar. Kandungan maksimum dari nilai salinitas air tawar yaitu $0,05-0,5 \%$. Sehingga air pada semua radius masih memenuhi standar kualitas air bersih (air tawar) [14].

Nilai $\mathrm{pH}$ juga dapat mempengaruhi kadar garam yang terkandung dalam suatu cairan. Karena air yang mengandung senyawa asam dan basa sekaligus akan memiliki sifat-sifat yang berbeda dan bergantung pada kekuatan asam atau basa yang terlarut. Air yang mengandung senyawa asam kuat dan basa kuat akan memiliki sifat netral dengan rasa yang asin. Hal tersebut dapat dilihat pada masing-masing radius dan dengan pengambilan yang berbeda. Dimana jika nilai $\mathrm{pH}$ air pada radius tersebut rendah maka nilai salinitas tinggi, begitu juga sebaliknya jika nilai $\mathrm{pH}$ tinggi, maka nilai salinitas rendah [15]

\section{Konduktivitas}

Konduktivitas merupakan kemampuan air dalam menghantarkan listrik. Gambar 9 menunjukkan nilai konduktivitas dari beberapa radius dan dengan pengambilan yang berbeda. Dalam gambar tersebut terlihat jika nilai konduktivitas untuk semua radius kecuali raidus $8 \mathrm{~km}$ cenderung naik di hari kedua dan menurun dihari ketiga.

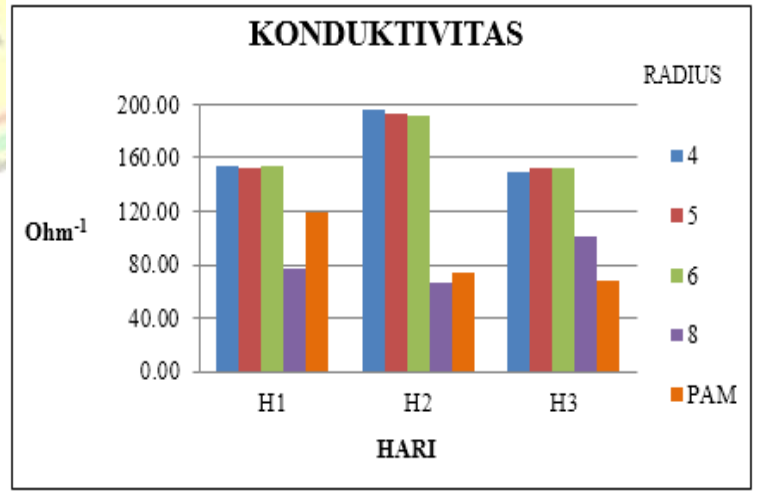

Gambar. 9. Hubungan nilai Konduktivitas dengan radius yang berbeda 
Perbandingan nilai konduktivitas antara radius satu dengan yang lainnya tidak begitu jauh berbeda. Akan tetapi terdapat satu radius yang memiliki nilai konduktivitas cukup tinggi dihari kedua, yaitu pada radius $4 \mathrm{~km}$. Nilai yang dihasilkan pada konduktivitas berbanding lurus dengan nilai TDS di atas. Dimana ketika nilai TDS besar, maka nilai konduktivitas juga besar dan sebaliknya ketika nilai TDS rendah maka nilai konduktivitas juga rendah. Dan faktor penyebab nilai tersebut juga sama dengan faktor perbedaan nilai pada TDS.

Sifat konduktivitas dipengaruhi pada jumlah kandungan yang disebut sebagai ion bebas. Air murni adalah air yang bebas kandungan ion bebas sehingga tidak menghantarkan listrik. Akan tetapi, air yang layak digunakan bagi manusia yaitu air dengan sifat konduktivitas yang cukup baik. Karena sifat konduktivitas yang cukup baik diperlukan bagi metabolisme tubuh manusia [4].

Selain ion bebas suhu juga menjadi salah satu faktor yang mempengaruhi nilai konduktivitas pada air. Dimana ketika suhu tinggi, maka nilai konduktivitas juga naik dan begitu juga sebaliknya jika suhu rendah maka nilai konduktivitas juga rendah [16].

\section{Resistivitas}

Berbanding terbalik dengan hasil dari nilai konduktivitas, resistivitas merupakan kemampuan yang dimiliki air dalam menghambat atau memperlambat aliran listrik. Dan nilai yang dihasilkan juga beerbanding terbalik dengan nilai konduktivitas di atas. Nilai resisitivitas untuk masing-masing cenderung sama terutama ntuk radius $4-6 \mathrm{~km}$.

Persamaan nilai tersebut juga dihasilkan pada hari yang berbeda. Akan tetapi pada hari kedua nilai resistivitas cenderung menurun dan naik kembali pada hari ketiga. Namun nilai tersebut masih berada di bawah nilai PAM yang digunakan sebagai pembanding. Sehingga pada radius 4-6 km nilai salinitas masih memenuhi syarat air yang baik. Pada radius $8 \mathrm{~km}$ nilai resistivitas sangat bervariasi dari pengambilan pertama hingga ketiga. Dimana pada radius $8 \mathrm{~km}$ nilai resistivitas cenderung sama hingga hari kedua, kemudian menurun dihari ketiga. Gambar 10 Menunjukkan hasil dari nilai resistivitas.

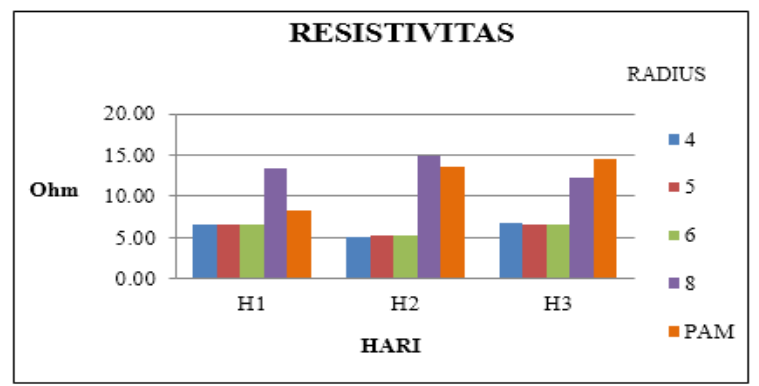

Gambar. 10. Hubungan nilai Resistivitas dengan radius yang berbeda

Pada sumur ketiga, nilai resistivitas naik dihari kedua dari hari pertama dan tetap pada hari ketiga. Dan nilai resistivitas pada radius $8 \mathrm{~km}$ lebih tinggi dibandingkan dengan radius lainnya. Dan untuk air PAM nilai resistvitas cenderung naik pada setiap pengambilan. Perbedaan nilai resisitivitas pada radius $8 \mathrm{~km}$ dapat disebabkan oleh lokasi sumur yang semakin jauh dari PKS. Dimana lokasi sumur tersebut berada pada dataran yang lebih rendah dibandingkan denga sumur lainnya.

Nilai resistivitas pada semua radius yang dihasilkan berbanding terbalik dengan nilai konduktivitas. Dimana ketika nilai dari konduktivitas tinggi maka nilai resistivitas akan rendah, dan begitu juga sebaliknya jika nilai konduktivitas rendah maka nilai resistivitas akan tinggi. Dan nilai yang dihasilkan pada resistivitas air untuk semua radius dan air PAM membuktikan perbandingan antara kedua nilai tersebut $[4,15]$.

\section{Rasa}

Uji organoleptik yang diberikan berupa uji rasa kepada 10 orang dewasa berjenis kelamin 5 pria dan 5 wanita yang berusia antara 25-39 tahun, dengan pilihan berasa (1) dan tidak berasa (2).

Tabel. 1. Hasil uji rasa sampel air sumur

\begin{tabular}{ccccccccccc}
\hline RADI & $\mathbf{P}$ & $\mathbf{P}$ & $\mathbf{P}$ & $\mathbf{P}$ & $\mathbf{P}$ & $\mathbf{P}$ & $\mathbf{P}$ & $\mathbf{P}$ & $\mathbf{P}$ & $\mathbf{P 1}$ \\
US & $\mathbf{1}$ & $\mathbf{2}$ & $\mathbf{3}$ & $\mathbf{4}$ & $\mathbf{5}$ & $\mathbf{6}$ & $\mathbf{7}$ & $\mathbf{8}$ & $\mathbf{9}$ & $\mathbf{0}$ \\
\hline 4 & 1 & 1 & 1 & 1 & 1 & 1 & 1 & 1 & 1 & 1 \\
5 & 1 & 1 & 1 & 1 & 1 & 1 & 1 & 1 & 1 & 1 \\
6 & 1 & 1 & 1 & 1 & 1 & 1 & 1 & 1 & 1 & 1 \\
8 & 1 & 1 & 1 & 1 & 1 & 1 & 1 & 1 & 1 & 1 \\
PAM & 1 & 1 & 1 & 1 & 1 & 1 & 1 & 1 & 1 & 1 \\
\hline
\end{tabular}


Dengan demikian air pada semua radius tersebut memenuhi syarat kualitas air bersih yang ditetapkan oleh Peraturan Menteri Kesehatan Republik Indonesia Nomor: 416 / MENKES / PER / IX / 1990 tentang syarat kualitas air bersih [6].

\section{KESIMPULAN}

Setelah melakukan analisa dari data yang telah dihasilkan maka dapat disimpulkan jika dari Hasil uji pH yang telah dilakukan terdapat tiga radius yang mendekati nilai standar PERMENKES yaitu radius 4, 5 dan $6 \mathrm{~km}$. Sedangkan untuk radius $8 \mathrm{~km}$ nilai $\mathrm{pH}$ jauh di bawah standar permenkes pada uji $\mathrm{pH}$. Kemudian untuk uji fisis semua radius sudah memenuhi standar PERMENKES, yaitu berupa uji viskositas, massa jenis, ORP, TDS, salinitas, konduktivitas, resistivitas, dan rasa. Sehingga dengan demikian berdasarkan uji $\mathrm{pH}$ air yang berada hanya pada radius 4, 5 dan 6 layak untuk dikonsumsi. Dan berdasarkan uji fisis air pada semua radius layak untuk dikonsumsi

\section{DAFTAR PUSTAKA}

Azwir. 2006. Analisa Pencemaran Air Sungai Tapung kiri Oleh Limbah Industri Kelapa Sawit PT. Peputra Masterindo Di Kabupaten Kampar, Tesis. Semarang. Universitas Diponegoro.

Nikmawati, Ellis E. 2007. Pentingnya Air dan Oksigen bagi Kesehatan Tubuh Manusia. Jakarta. Universitas Pendidikan Indonesia.

Irawan M. Anwari. 2007. Cairan Tubuh, Elektrolit \& Mineral.

Pitoyo, Amrih. 2005. Dua Jam Anda Tahu Cara Memastikan Air Yang Anda Minum Bukan Sumber Penyakit. Solo. Nomor seri $e$-buku 05-0000-100-0220 Distribusi Terbuka.

Departemen Pekerjaan Umum Badan Penelitian Badan Penelitian Dan Pengembangan. 2004. Penyediaan Air Bersih. Jakarta. Pusat Penelitian Dan Pengembangan Sosial Ekonomi Budaya Dan Peran Masyarakat.
Peraturan Menteri Kesehatan Republik Indonesia Nomor : 416/MENKES/PER/IX/1990 tentang syarat kualitas air bersih Peraturan Menteri Kesehatan No. 416 Tahun 1990 Tentang : Syarat-syarat Dan Pengawasan Kualitas Air.

Warlina, Lina. 2004. Pencemaran Air: Sumber, Dampak Dan Penanggulangannya. Bogor. Makalah Pribadi, Istitut Pertanian Bogor.

Mariance, Rince. 2006. Karakteristik Fisik dan pH Sari Wortel. Bogor. Institut Pertanian Bogor. Skripsi.

Budianto, Anwar. 2008. Metode Penentuan Koefisien Kekentalan Zat Cair Dengan Menggunakan Regresi Linier Hukum Stokes. Seminar Nasional SDM Teknologi Muklir Yogyakarta, 25-26 Agustus 2008. ISSN 1978-0176.

Fitriyanto, dkk. 2013. Kajian Viskositas Dan Berat Jenis Susu Kambing Peranakan Etawa (Pe) Pada Awal, Puncak Dan Akhir Laktasi. Purwokerto. Fakultas Peternakan, Universitas Jendral Soedirman Purwokerto.

Sears dan Zemansky. 1999. Fisisa Universitas Edisi 10 Jilid 1. Jakarta. Erlangga.

Hazmi Ariadi, dkk. 2012. Penghilangan Mikroorganisme dalam Air Minum dengan Dielectric Barrier Discharge. Padang.Jurusan Teknik Kimia, Fakultas Teknologi Industri, Universitas Bung Hatta.

Quality Assurance Departement. PT Ades Waters Indonesia Tbk.

Himati Ikfina dan Endarko. 2013. Pembuatan Elektroda dan Perancangan Sisitem Capacitive Deionization untuk mengurangi Kadar Garam Pada Larutansodium Clorida $(\mathrm{NaCl})$. Surabaya. Jurusan Fisika, Fakultas MIPA, Institut Teknologi Sepuluh Nopember. Berkala Fisika ISSN : $1410-$ 9662 Vol. 16, No. 3, Juli 2013, hal 67 74. 
Kurnian Alfa, dkk. Identifikasi Kualitas Air Berdasarkan Nilai Resistivitas Air. Yogyakarta. Studi Kasus: Kali Gajahwong

Zuhra Cut. F. 2006. Flavor (Cita Rasa). Medan.
Karya Ilmiah Universitas Sumatra Utara. Purwanto dkk. 2004. Pengaruh Suhu Terhadap Konduktivitas Elektrolit Padat. Tangerang. Puslibang Iptek Bahan (P3IB)-Batan

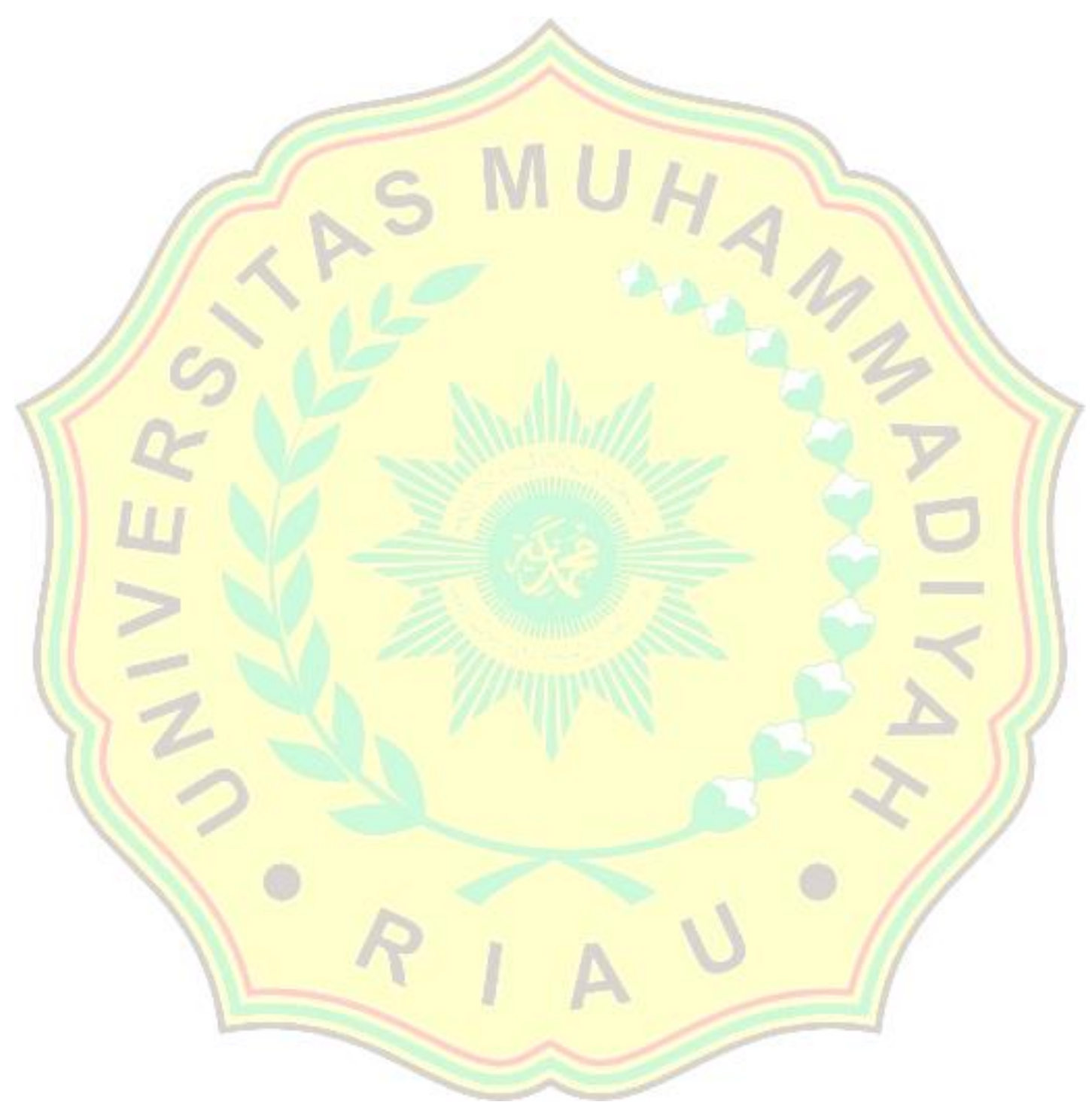


